\title{
Why Promote Improved Fallows as a Climate-Smart Agroforestry Technology in Sub-Saharan Africa?
}

\author{
Samuel T. Partey ${ }^{1, *,+}$ (D) , Robert B. Zougmore ${ }^{1,+}$, Mathieu Ouédraogo ${ }^{1,+}$ (i) and \\ Naresh V. Thevathasan $2,+$ \\ 1 CGIAR Research Program on Climate Change, Agriculture and Food Security, International Crops Research \\ Institute for the Semi-Arid Tropics, Bamako BP 320, Mali; R.Zougmore@cgiar.org (R.B.Z.); \\ M.Ouedraogo@cgiar.org (M.O.) \\ 2 School of Environmental Sciences, University of Guelph, Guelph, ON N1G 2W1, Canada; \\ nthevath@uoguelph.ca \\ * Correspondence: S.Partey@cgiar.org; Tel.: +223-20709200 \\ + All authors contributed equally to the development of the manuscript and have approved the \\ final manuscript.
}

Received: 13 September 2017; Accepted: 17 October 2017; Published: 26 October 2017

\begin{abstract}
In the literature, a lot is discussed about how agroforestry can achieve the mitigation, adaptation and productivity goals of climate-smart agriculture (CSA). However, this may be relatively too broad to assess the trade-offs and synergies of how specific agroforestry technologies or practices achieve the three pillars of CSA. Here, we provide an overview of how improved fallows (an agroforestry technology consisting of planting mainly legume tree/shrub species in rotation with cultivated crops) may achieve the goals of climate-smart agriculture in Sub-Saharan Africa (SSA). Our review showed that improved fallow systems have real potential to contribute to food security and climate change mitigation and adaptation in SSA. Under proper management, improved fallows can increase maize yields to about $6 \mathrm{t} \mathrm{ha}^{-1}$, which is comparable to conventional maize yields under fertilization. This is attributed to improved soil fertility and nutrient use efficiency. Although data was generally limited, the growing literature showed that improved fallows increased soil carbon sequestration and reduced greenhouse emissions. Further, as a multiple output land use system, improved fallows may increase fodder availability during dry periods and provide substantial biomass for charcoal production. These livelihood options may become important financial safety nets during off seasons or in the event of crop failures. This notwithstanding, the adoption of improved fallows is mainly in Southern and Eastern Africa, where over 20,000 farmers are now using Sesbania sesban, Tephrosia vogelii, and Cajanus cajan in two-year fallows followed by maize rotations. Land tenure issues, lack of social capital, and improved germplasm and accessions of fallow species have been cited as constraints to scaling up. However, development of seed orchards, nursery development, and the willingness of policy makers to create a policy environment that addresses market failures and alleviates disincentives should improve adoption and future scaling up.
\end{abstract}

Keywords: agroforestry; food security; climate change; adaptation; mitigation

\section{Introduction}

Among several essential needs of humankind such as health care, primary and secondary education, and sanitation, the basic requirements are food, water, clothing, and shelter. Among these requirements, there is inequality in the accessibility of adequate food supply. To all developmental experts, this state of inequality poses a massive challenge and inexcusable failure in addressing food insecurity, which results in hunger and desperate poverty that stunts the lives of the disadvantaged and excluded [1,2]. Although humans have lived with food insecurity for centuries, the impact is expected 
to be greater with the current rise in world population unless issues governing food production are effectively addressed. Having adequate food supply is not a sufficient condition to ensure food security [2]. Accessibility to food and food utilization should also be developed in parallel in order to achieve economic prosperity [2]. Improving soil fertility and maintaining an adequate supply of nutrients in agroecosystems have significant implications for meeting the food security agenda as highlighted in the Sustainable Development Goals. In sub-Saharan Africa (SSA), declining soil fertility and mismanagement of plant nutrients have made this task more difficult even when improved varieties of crops are currently available [3]. In addition, climate change continues to exacerbate already tight resource constraints by making weather more extreme and variable and by decreasing average yields worldwide [4]. Already, these pressures are forcing farmers and researchers to reassess mainstream farming techniques and consider alternative approaches to securing food. Recent advances in global agricultural research have been focusing on the questions of increasing the resilience (against drought, erosion, fertility loss, etc.) and productivity of agricultural systems, which are directly related to increasing the adaptive capacity of farmers [5]. Climate-smart agriculture (CSA) can contribute to achieving this development agenda as it fosters the development and implementation of agriculture innovations that (1) sustainably increases agricultural productivity to support equitable increases in incomes, food security, and development; (2) adapts and builds resilience to climate change from the farm to national levels; and (3) develops opportunities to reduce greenhouse gas emissions from agriculture compared with past trends [4].

Like most agroforestry practices, improved fallows (an agroforestry technology consisting of planting mainly legume tree/shrub species in rotation with cultivated crops) can contribute to food security, climate change mitigation and adaptation, and sustainable conservation of natural resources [6]. With woody perennials as integral components, improved fallows fall under the category of landscape-scale mitigation schemes under the REDD+ (Reduction Emissions from Deforestation and forest Degradation) and AFOLU (Agriculture, Forestry, and other land uses) concepts [5]. In the literature, a lot is discussed about how agroforestry as an umbrella term for land use systems integrating trees with crops and/or animals achieves the mitigation, adaptation and productivity goals of climate-smart agriculture (CSA) [7-10]. For instance, Kim et al. [11] reported agroforestry mitigates $27 \pm 14 \mathrm{t} \mathrm{CO}_{2}$ equivalent ha ${ }^{-1}$ year $^{-1}$, which is significant to reducing global carbon emissions. Quandt et al. [12] also found agroforestry was a key adaptation strategy to climate change in Sub-Saharan Africa (SSA). Further, the reports of Abbas et al. [7], Coulibaly et al. [8], and Hunde [9] all confirmed agroforestry improves the biological productivity of crops for household food and nutritional security. While the literature provides the necessary evidence to invest in agroforestry as a climate-smart option, they are rather generalized, making it unclear as to how specific agroforestry technologies or practices such as improved fallows achieve the mitigation, adaptation and productivity goals of CSA. In SSA, large-scale, landscape-level adoption of improved fallows is yet to be achieved, although it has great potentials for simultaneous achievement of the three pillars of CSA. Therefore, as countries continue to review their national agriculture investment and climate change adaptation plans, information on the "climate-smartness" of improved fallows will be crucial for informing its inclusion into national agricultural development plans. In this paper, we provide an overview (based on empirical evidence) as to how improved fallows may achieve the goals (productivity, mitigation, and adaptation) of CSA so that future scaling-up in SSA can be rooted in robust scientific findings rather than on the intuitions of development actors.

\section{How Improved Fallows May Increase Production and Contribute to Food Security}

With agriculture being a soil based industry, agricultural practices that improve soil fertility will make huge contributions to achieving food security [2]. In most parts of SSA, farmers use improved fallows as a strategy for improving soil fertility within a shorter time-period, compared with natural fallow [13]. The fallow phase may differ based on soil conditions, fallow species and farmer preference. However, a fallow phase of between six months to three years is commonly reported [14]. For the 
same level of soil degradation, a longer fallow phase may improve soil fertility better [15]. According to Amadalo et al. [14], the residual effect from a short-duration improved fallow may last one to two seasons, but the effect of an eight-month fallow can last for one or more seasons, depending on the level of degradation of the soil. At the end of the fallow period, the trees, shrubs, or herbaceous legumes are cut down, and the biomass (leaves, twigs, branches) is incorporated into the soil while the land is being prepared for the next crop. Table 1 shows examples of herbaceous and tree species commonly used in improved fallows. The legume species generally improve the soil through biological nitrogen fixation whereby recycled nutrients are deposited through litter or when biomass is harvested at the end of the fallow period and is incorporated into the soil $[16,17]$. The technology is recognized as cost-effective and a viable alternative to inorganic fertilizers $[15,18]$. A well-managed improve fallow system may contribute between $100 \mathrm{~kg} \mathrm{~N} \mathrm{ha}^{-1}$ year $^{-1}$ and $200 \mathrm{~kg} \mathrm{~N}^{-1}$ year $^{-1}$ [14]. With adequate water supply and available phosphorus and potassium in soil, a nitrogen supply of 100 to $200 \mathrm{~kg} \mathrm{ha}^{-1}$ can produce about 4 to 5 tonnes of maize grain in one growing season [14].

Evidence of improved soil fertility and increased crop productivity with improved fallows have been observed across sub-Saharan Africa. In Zambia, field studies conducted on-station showed improved fallows with Sesbania sesban increased maize yields with or without application of mineral fertilizers [19]. Maize grain yields of 5.0 and $6.0 \mathrm{t} \mathrm{ha}^{-1}$ were obtained following two- and three-year S. sesban fallows, respectively. This compared to 4.9 and $4.3 \mathrm{tha}^{-1}$ from continuously cropped maize with fertilizer $\left(112 \mathrm{~kg} \mathrm{~N} \mathrm{ha}^{-1}\right)$ and 1.2 and $1.9 \mathrm{t} \mathrm{ha}^{-1}$ without fertilizer. In addition, the fallows had strong residual effects on maize yields. Total yield in four cropping seasons following the two-year fallow was $12.8 \mathrm{t} \mathrm{ha}^{-1}$ compared to $7.6 \mathrm{t} \mathrm{ha}^{-1}$ for six seasons of continuous unfertilized maize. In Western Kenya, farmers also reported maize yield increment of up to $200 \%$ from improved fallows [20]. In Malawi, Kwesiga et al. [21] reported S. sesban rotational woodlot fallow increased maize yields compared to plots fertilized with inorganic nitrogen. On an Alfisol of Nigeria, leguminous tree fallows of Cajanus cajan, Crotalaria grahamiana, S. sesban, and Tephrosia candida accumulated $100-200 \mathrm{~kg} \mathrm{~N} \mathrm{ha}^{-1}$ between six months and two years. Biomass transfer from the species increased maize yield by 4 times compared with unamended controls $[17,22]$. In northern Ghana, improved fallow with Callopogonium mucunoides significantly increased the yield of rice compared with natural fallows and chemical fertilizer treatments [23]. Furthermore, an improved fallow system with Mucuna pruriens in the semi-arid tropics of Zimbabwe showed increased maize water productivity and soil fertility [24]. Under nutrient poor conditions, Masikati et al. [24] found that soil organic carbon and total nitrogen increased by $2.6-194 \mathrm{~kg} \mathrm{ha}^{-1}$ year $^{-1}$ and 6-14 $\mathrm{kg} \mathrm{ha}^{-1}$ year $^{-1}$, respectively. 
Table 1. Some examples of trees/shrub legumes used for improved fallows in Sub-Saharan Africa (SSA).

\begin{tabular}{|c|c|c|c|c|}
\hline Scientific Name & Common Name (s) & Description & Climate Range & Reference \\
\hline Sesbania sesban & $\begin{array}{l}\text { Sesban, Egyptian rattle pod, frother, } \\
\text { sesbania, river bean }\end{array}$ & $\begin{array}{l}\text { A narrow-crowned, deep-rooting single or } \\
\text { multistemmed shrub or small tree, } \\
1-7 \mathrm{~m} \text { tall }\end{array}$ & $\begin{array}{l}\text { Cooler, higher elevation regions of } \\
\text { the tropics }\end{array}$ & Orwa et al. [25] \\
\hline Tephrosia vogelii & $\begin{array}{l}\text { Vogel's tephrosia, fish-poison-tree, } \\
\text { fish-poison bean, fish bean }\end{array}$ & $\begin{array}{l}\text { A soft, woody branching herb or small tree } \\
\text { with dense foliage, } 0.5-4 \mathrm{~m} \text { tall }\end{array}$ & Semi-arid, humid, sub-humid tropics & Orwa et al. [25] \\
\hline Calliandra calothyrsus & $\begin{array}{l}\text { Red calliandra, kalliandra merah, } \\
\text { calliandra, }\end{array}$ & $\begin{array}{l}\text { A small, thornless, often multistemmed } \\
\text { shrub. Under optimum conditions it can } \\
\text { attain a height of } 12 \mathrm{~m} \text { and a trunk } \\
\text { diameter of } 30 \mathrm{~cm} \text {, but its average height is } \\
5-6 \mathrm{~m} \text { and diameter } 20 \mathrm{~cm}\end{array}$ & Humind and sub-humid tropics & Orwa et al. [25] \\
\hline Senna spectabilis & $\begin{array}{l}\text { Calceolaria shower, pisabed, cassia, } \\
\text { yellow shower }\end{array}$ & $\begin{array}{l}\text { Shrub and medium-sized tree; grows to } \\
\text { about } 15 \mathrm{~m} \text { tall }\end{array}$ & $\begin{array}{l}\text { Tropical and tolerant of cool } \\
\text { conditions }\end{array}$ & Orwa et al. [25] \\
\hline Gliricidia sepium & $\begin{array}{l}\text { Gliricidia, tree of iron, St. Vincent plum, } \\
\text { Mexican lilac, mother of cocoa, quick } \\
\text { stick, Nicaraguan cacao shade }\end{array}$ & Shrub; grows to a height of $2-15 \mathrm{~m}$ & Tropical & Orwa et al. [25] \\
\hline Leucaena leucocephala & $\begin{array}{l}\text { Leucaena, Jumpy-bean, wild tamarind, } \\
\text { lead tree, white popinac, white leadtree, } \\
\text { horse tamarind }\end{array}$ & $\begin{array}{l}\text { Shrub and medium-sized tree; grows to } \\
\text { about } 15 \mathrm{~m} \text { tall }\end{array}$ & Tropical & Orwa et al. [25] \\
\hline Acacia auriculiformis & $\begin{array}{l}\text { Earpod wattle, Papuan wattle, auri, } \\
\text { earleaf acacia, northern black wattle, } \\
\text { Darwin black wattle }\end{array}$ & An evergreen tree; grows to about $15 \mathrm{~m}$ tall & $\begin{array}{l}\text { Mostly tropical but also found in } \\
\text { some temperate ecologies as an } \\
\text { introduced ornamental }\end{array}$ & Starr et al. [26] \\
\hline Senna siamea & $\begin{array}{l}\text { Kassod tree, yellow cassia, cassia, } \\
\text { Thailand shower, thai copper pod, iron } \\
\text { wood, Siamese senna, Bombay } \\
\text { blackwood, black-wood cassia }\end{array}$ & $\begin{array}{l}\text { A medium-size, evergreen tree growing up } \\
\text { to } 18 \mathrm{~m} \text { tall }\end{array}$ & $\begin{array}{l}\text { Lowland tropics with a monsoon } \\
\text { climate }\end{array}$ & Orwa et al. [25] \\
\hline Tephrosia candida & $\begin{array}{l}\text { White hoary pea, hoang pea, } \\
\text { white tephrosia }\end{array}$ & $\begin{array}{l}\text { An erect herb, shrub or small tree, up to } \\
3.5 \mathrm{~m} \text { tall, } \\
\text { with straggling branches from the base }\end{array}$ & Dry tropics & Orwa et al. [25] \\
\hline Cajanus cajan & $\begin{array}{l}\text { Congo pea, pigeon pea, red gram, } \\
\text { yellow dahl }\end{array}$ & $\begin{array}{l}\text { An erect woody, annual or short-lived } \\
\text { perennial shrub or small tree, } 1-4 \mathrm{~m} \text { tall } \\
\text { with a deep taproot (to } 2 \mathrm{~m} \text { ) }\end{array}$ & Tropics and subtropics & Nene et al. [27] \\
\hline
\end{tabular}




\section{Climate Change Mitigation Aspects of Improved Fallows}

\subsection{Carbon Sequestration}

Although soil fertility amelioration is the primary objective of most improved fallow systems, they have the potential to mitigate climate change through carbon sequestration. Considering relatively high biomass productivity (Table 2), increased soil $\mathrm{C}$ pool could be expected. In several parts of SSA, significant increase in soil organic matter has been reported with planted fallows of Cajanus cajan on degraded soils in western Kenya [28], Tephrosia vogelii in Cameroon [6], Tephrosia candida and C. cajan in Nigeria [29], and in single and mixed legume species stands in western Kenya [30]. In Southeastern Nigeria, Mutuo et al. [31] found increased soil C stocks in the top $5 \mathrm{~cm}$ soil depth by about $1.5 \mathrm{Mg} \mathrm{C} \mathrm{ha}^{-1}$ within a two-year fallow with C. cajan. Similarly, a 1.5-year fallow of Sesbania sesban in western Kenya increased soil C stocks in the top $15 \mathrm{~cm}$ depth by about $2.5 \mathrm{Mg} \mathrm{C} \mathrm{ha}{ }^{-1}$. Again, the review by Mutuo et al. [31] in Western Kenya showed increased soil C stocks up to $0.9 \mathrm{Mg} \mathrm{C} \mathrm{ha}^{-1}$ in fields where fallow biomass of Crotalaria grahamiana was incorporated with tilling and about 1.6 $\mathrm{Mg} \mathrm{C} \mathrm{ha}{ }^{-1}$ in with no-till practices. Table 3 reports some country specific increase in SOC following improved fallows under different soil conditions. Additionally, the potential $\mathrm{C}$ sequestration rate in a three-planted fallow could be $1.30 \pm 0.13$ [32], similarly reported for reforested degraded agriculture lands, pasture fields, and secondary forests [32,33], which substantiate the role of improved fallows in climate change mitigation.

Table 2. Biomass productivity of some improved fallow species in western Kenya [34].

\begin{tabular}{cccc}
\hline Fallow Species & Above-Ground Biomass & Below-Ground Biomass & Total (Mg ha $\left.\mathbf{~}^{\mathbf{1}}\right)$ \\
\hline 12-month-old fallows & & & \\
C. grahamiana & 8.5 & 2.7 & 11.2 \\
C. calothyrsus & 21.0 & 7.0 & 28.0 \\
C. cajan & 8.5 & 3.9 & 12.4 \\
S. spectabilis & 7.0 & 4.8 & 11.8 \\
S. sesban & 14.2 & 7.3 & 21.5 \\
T. vogelii & 10.8 & 4.0 & 14.8 \\
\hline 18-month-old fallows & & & 35.6 \\
C. grahamiana & 24.7 & 10.9 & 33.4 \\
C. paulina & 19.8 & 13.6 & 64.2 \\
T. candida & 31.0 & 33.2 & \\
\hline 22-month-old fallows & & & 42.5 \\
C. calothyrsus & 27.0 & 15.5 & 47.7 \\
S. sesban & 36.9 & 10.8 & 50.3 \\
Grevillia robusta & 32.6 & 17.7 & 62.5 \\
Eucalyptus saligna & 43.4 & 19.1 & \\
\hline
\end{tabular}

Table 3. Increase in soil organic carbon (SOC) following improved fallows with different species [34].

\begin{tabular}{cccccc}
\hline Fallow Species & Age (Years) & Country & Soil Type & Sampling Depth $(\mathbf{c m})$ & SOC Increase $\left(\mathbf{M g}\right.$ ha $\left.^{-\mathbf{1}}\right)$ \\
\hline A. auriculiformis & 5 & Togo & Ferric Acrisol & $0-10$ & 3.41 \\
A. lebbek & 5 & Togo & Ferric Acrisol & $0-10$ & 5.21 \\
A. indica & 5 & Togo & Ferric Acrisol & $0-10$ & 12.46 \\
C. cajan & 1 & Kenya & Deep red loam & $0-30$ & 0.73 \\
C. siamea & 5 & Togo & Ferric Acrisol & $0-10$ & 5.2 \\
C. grahamiana & 1.5 & Kenya & Arenosol & $0-20$ & 1.69 \\
C. grahamiana & 1.5 & Kenya & Ferralsol & $0-20$ & 3.6 \\
C. paulina & 1.5 & Kenya & Arenosol & $0-20$ & 2.15 \\
C. paulina & 1.5 & Kenya & Ferralsol & $0-20$ & 8.94 \\
L. leucocephala & 1 & Kenya & Ferralsol & $0-30$ & 3.1 \\
S. sesban & 1 & Kenya & Ferralsol & $0-30$ & 3.74 \\
T. candida & 1.5 & Kenya & Ferralsol & $0-20$ & 2.58 \\
T. vogelii & 1.5 & Kenya & Ferralsol & $0-20$ & \\
\hline
\end{tabular}




\subsection{Greenhouse Gas Emission}

Data on greenhouse gas emissions from soils in SSA are limited with few short-term, seasonal investigations or laboratory incubations, which may not be enough to understand the level of emissions under field conditions [35]. There is, however, growing evidence from the literature to reasonably assume that the integration of tree/shrub legumes into cropping systems may not constitute a significant environmental threat in relation to greenhouse emissions. For instance, Verchot et al. [36] reported that improved fallows of Inga edulis and Acacia mangium in an old agricultural frontier on sandy soils did not appear to decrease the soil $\mathrm{CH}_{4}$ sink and also do not seem to increase $\mathrm{CO}_{2}$ and $\mathrm{N}$-oxide emission. In addition, no significant difference in $\mathrm{CH}_{4}$ flux between improved fallows and unimproved fallows (control) was observed in both wet and dry seasons. In Western Kenya, a short-term experiment showed that without tillage, an improved fallow system involving the application of T. candida residues could lower total $\mathrm{N}_{2} \mathrm{O}$ and $\mathrm{CO}_{2}$ emitted over 99 days by $0.33 \mathrm{~g}$ $\mathrm{N}_{2} \mathrm{O}-\mathrm{N}$ ha ${ }^{-1} \mathrm{~kg} \mathrm{~N}$ applied $^{-1}$ and $124 \mathrm{~kg} \mathrm{CO}_{2}-\mathrm{C} \mathrm{ha}^{-1} \mathrm{t} C$ applied $^{-1}$, respectively. This can be estimated to provide a reduction in global warming potential of $41 \mathrm{~g} \mathrm{CO}_{2}$ equivalents [37]. Conversely, Millar et al. [38], showed that $\mathrm{N}_{2} \mathrm{O}$ and $\mathrm{CO}_{2}$ emissions may typically increase in improved fallow systems after addition of residues, since organic material is often readily decomposed and $\mathrm{N}_{2} \mathrm{O}$ subsequently produced during nitrification and denitrification. More field level data from long-term experiments is required to assess the regional greenhouse gas budgets in absolute terms.

\section{Climate Change Adaptation Aspects of Improved Fallows}

\subsection{Reduced Incidences of Weeds, Pests, and Diseases}

Climate change may impact on the incidences of pest and diseases in agroecosystems. For instance, elevated $\mathrm{CO}_{2}$ are expected to increase levels of simple sugars in leaves and lower their nitrogen content, which will provide the enabling environment for increased damages caused by many insects, who will consume more leaves to meet their metabolic requirements of nitrogen. In addition, the effectiveness of pesticides may be reduced by warmer temperatures and favour the insect carriers of many disease pathogens and natural enemies of pests and diseases [39]. Meanwhile, the growing evidence that improved fallows reduce pests and diseases means it could improve the adaptive capacity of agroecosystems under changing climate to minimize yield losses to pests and diseases [40]. In Zambia, a rotational improved tree fallow system involving Sesbania sesban reduced the incidence of Stiga asiatica on subsequent maize under three consecutive seasons compared with fields continuously cropped with maize or under traditional bush fallow systems [40]. S. sesban is known to cause suicidal germination of Striga sp. and cripple its growth and development by improving soil inorganic N [29]. Similarly, field experiments in Kenya confirmed 34\% reduction in Striga hermonthisa seeds in soils under improved fallows compared with maize monocultured fields, recording $11 \%$ increase during the same cropping period [41]. The thick mulch layer of tree fallows reportedly suppressed perennial grasses such as Imperata cylindrical and the general weed biomass of arable lands in Nigeria and Zambia [42]. While improved fallows could significantly reduce yield losses to pests, weeds, and diseases, contrasting reports in Southern Africa [43], Tanzania [44], and Western Kenya [45] concerning increased plant-parasitic nematodes (such as Meloidogyne and Pratylenchus spp.) and insect crop pests such as Diaecoderus sp. after rotational tree fallows with Cajanus cajan, Tephrosia vogelii, and Crotalaria grahamiana suggest the selection of tree legumes for improved fallows will be key for experiencing net positive effects in agroecosystems.

\subsection{Soil Water Conservation}

With only $4 \%$ (about 6 million ha) of the total cultivated area of SSA under irrigation, irrigation contributes only a little to the mostly rain-fed production systems [46] in the region. This makes the region vulnerable to climate change and variability. Climate-smart technologies that improve the efficient use of green water (rain water available in soil for plant use) could be one viable option for 
reducing climate-related risks. Like most agroforestry systems, improved fallows have been shown to improve and conserve soil moisture for crop production [18]. Contributions of litter fall to reducing soil water evaporation and improving soil structure are reported [47]. Phiri et al. [48] also found improved soil aggregation in tree fallowed fields that enhanced water infiltration, soil water holding capacity, and reduced run off and erosion compared with fields continuously cropped with maize.

\subsection{Potential Fodder Production during Dry Periods}

Without appropriate interventions, changing climatic conditions such as drought negatively impacts livestock and associated livelihoods [49,50]. With livestock in SSA mostly kept under free-range systems, repeated occurrence of droughts lead to scarcity of fodder with fair nutritive value that impedes livestock productivity. Even when animals are stall-fed on crop residues during pasture scarcity periods, the dry matter intake and protein requirements of animals are often not met [51-53]. Recent studies have shown dry season feeding from leaves of drought tolerant tree/shrub legumes used in improved fallows systems offer many advantages such as supply of good quality green fodder, and high crude protein and minerals to animals [54,55]. In Sudan, Elseed et al. [55] reported that tree legumes could produce fodder of comparable nutritional composition during early and late dry periods. Table 4 shows the nutritional composition of fodder of some tree/shrubs used in improved fallows but also served as feed for livestock in SSA during dry periods. Although the species are generally drought-tolerant, values on biomass productivity during droughts have not been extensively studied. However, there are clear indications that compared with herbaceous vegetation, supplementary feed supply from tree legumes could be substantial during dry periods [55]. Meanwhile, the long-term sustenance of supplementary fodder supply from improved fallow species during dry periods or droughts have to be extensively studied. As fodder harvest during dry periods may reduce carbohydrate reserves and impair the regenerative ability of trees to produce new shoots [56] due to rainfall scarcity, the contribution of tree litter to soil enrichment during the fallow phase could be compromised. However, this has to be verified in long term experiments.

Table 4. Nutritional composition of fodder legumes used for improved fallows in Sub-Saharan Africa.

\begin{tabular}{|c|c|c|c|c|c|c|}
\hline Fodder Species & $\begin{array}{l}\text { Crude } \\
\text { Protein }\end{array}$ & $\begin{array}{l}\text { Crude } \\
\text { Fibre }\end{array}$ & $\begin{array}{c}\text { Acid Detergent } \\
\text { Fibre }\end{array}$ & $\begin{array}{c}\text { Neutral } \\
\text { Detergent Fibre }\end{array}$ & $\begin{array}{l}\text { Total } \\
\text { Ash }\end{array}$ & Reference \\
\hline Acacia ehrenbergiana & 274 & - & 154 & 191 & - & Elseed et al. [55] \\
\hline Acacia mellifera & 218 & - & 167 & 215 & - & Elseed et al. [55] \\
\hline Acacia nilotica & 214 & 305 & - & - & 117 & Abdalla et al. [57] \\
\hline Acacia nubica & 285 & - & 133 & 182 & - & Elseed et al. [55] \\
\hline Acacia seyal & 197 & - & 160 & 202 & - & Elseed et al. [55] \\
\hline Acacia tortilis & 257 & - & 165 & 203 & - & Elseed et al. [55] \\
\hline Afzelia africana & 178 & 278 & 260 & - & 130 & Smith [58] \\
\hline Albizia lebbeck & 217 & 366 & 246 & 354 & 73 & Smith [58] \\
\hline Cajanus cajan & 22.8 & 201 & - & - & 58 & Devendra [59] \\
\hline $\begin{array}{l}\text { Calliandra } \\
\text { calothyrsus }\end{array}$ & 240 & 217 & - & - & 80 & Devendra [59] \\
\hline $\begin{array}{l}\text { Cyclicodiscus } \\
\text { gabunensis }\end{array}$ & 158 & 210 & 230 & - & 50 & Smith [58] \\
\hline Dichrostachys cinerea & 98 & - & 474 & 479 & 69 & Shenkute et al. [60] \\
\hline Erythrina variegata & 258 & 174 & - & - & 67 & Devendra [59] \\
\hline Ficus exersperata & 148 & 220 & 250 & - & 70 & Smith [58] \\
\hline Gliricidia sepium & 230 & 207 & 287 & 428 & 97 & Smith [58] \\
\hline Leucaena leucocephala & 224 & 130 & 289 & 420 & 94 & Smith [58] \\
\hline Prosopis cineraria & 140 & 178 & - & - & 69 & Devendra [59] \\
\hline Sesbania grandiflora & 235 & - & 217 & 271 & 100 & Smith [58] \\
\hline
\end{tabular}

\subsection{Provision of Biomass Resource for Off-Season Charcoal Production as Safety-Net}

With increasing climate variability, the risks of crop or production system failure are always high without appropriate interventions. Vulnerable farmers therefore diversify production and income streams as a pathway to reduce vulnerability to climate-related risks. In SSA, off-season charcoal 
production for income generation is a common practice among resource-poor farmers. Income from charcoal sales (1) provide safety-nets in times of shortfalls in incomes derived from arable farming, livestock, or fisheries, (2) support current charcoal/wood fuel consumption, and (3) serve as a potential pathway out of poverty $[61,62]$. With a projected rise in the consumption of wood fuels and charcoal by 2030, economic returns from wood fuels and charcoals are also expected to rise [53]. However, except where community or individual plantations designated for charcoal production are in place, farmers are confronted with the challenges of meeting biomass resource demands due to evolving natural resource management policies that restrict harvest of wood biomass from forests. With improved fallows, tree legumes could provide biomass resource for charcoal production at the end of the fallow phase. The wood biomass of species such as S. sesban, C. calothyrsus, G. sepium, L. leucocephala, and Acacia auriculiformis are widely used as firewood or charcoal in SSA. Orwa et al. [25] reported that the high wood biomass of the species, their relatively fast growth rates, coppiceability, and high calorific values make them good choices among farmers for off-season income generation. In addition, 15 and $21 \mathrm{t} \mathrm{ha}^{-1}$ of fuelwood were harvested after two- and three-year fallows, respectively [19].

\section{Adoptability and Up-Scalability of Improved Fallows in SSA}

According to Whiteside [63], improved fallow is most popular in Southern Africa and had made its greatest impact in the region. It is estimated that about 20,000 farmers are now using Sesbania sesban, Tephrosia vogelii and Cajanus cajan in two-year fallows followed by maize rotations for two to three years [61]. In Benin, Maliki et al. [64] showed that farmers adopted the use of herbaceous legumes (especially Mucuna pruriens) in yam-based croppings for improved soil fertility and yield. The attractiveness to improved fallow technologies has not been attributed to the effectiveness in soil fertility amelioration alone but also the tangible economic benefits [65]. In the highlands of East Africa, farmers with 500 calliandra shrubs increased their net income by between US\$ 62 to 122 depending on whether they used shrubs as a substitute, or as supplement, and depending on where they were located [66]. This notwithstanding, Ajayi et al. [67] identified factors such as lack of permanent ownership rights over land, incidence of bush fires, and browsing of tree biomass by livestock as major constraints to adopting and scaling up improved fallows in Zambia. Drawing on the available literature, in particular the reviews of Franzel [68] and Place and Dewees [69], several factors are most likely to affect adoption of improved fallows like other agroforestry innovations: biophysical adaptation of the innovation - the ability of the innovation to adapt and be adapted successfully to the farm environment, the profitability of the innovation-in a broad sense to include consideration of returns to labour and land as well as financial profitability; farmers' awareness of the innovation; access to land, labour, and water; access to social capital, particularly where group action is needed; availability of essential inputs, particularly seed; access to financial capital; and degree of risk and uncertainty. Furthermore, Sanchez [70] cited the supply of germplasm of improved fallow species and accessions as one limiting factor for scaling up which is greatly being tackled through seed orchards and nursery development. This notwithstanding is still an opportunity for scaling up. This will dwell pragmatically on increasing awareness, on-farm research, capacity building using farmer-field school extension approaches etc. Considering the role of policies on the adoption of any natural resource management practice, Place and Dewees [69] recommended the following areas as key to getting policies right with respect to improved fallows: (1) mineral fertilizer policy, (2) planting material production and distribution, and (3) property rights to ensure that farmers can invest in fallows and reap the benefits. In addition, it is important that policy makers create a policy environment which addresses market failures and alleviates disincentives for adoption of improved fallow systems.

\section{Conclusions}

This review showed that, like most agroforestry innovations, improved fallows has real potential to contribute to food security and climate change mitigation and adaptation in Sub-Saharan Africa (SSA). Under proper management, improved fallows can increase maize yields to about $6 \mathrm{t} \mathrm{ha}^{-1}$ with 
residue addition. With the integration of trees/shrubs, significant carbon could be sequestered. While results on emissions from tree residue decomposition and denitrification are contrasting, the growing evidence from the literature suggests improved fallows may not pose significant environmental threats in relation to greenhouse emissions. There is however substantial knowledge gap on the trade-offs and synergies among the productivity, adaptation, and mitigation goals of improved fallows. Generating empirical evidence (through research) to close these knowledge gaps and support decision-making processes that achieve win-win scenarios under different contexts will be crucial to improving the adoption of improved fallows as a climate-smart option for farmers and decision makers in SSA. This notwithstanding, improved fallows present new vistas of opportunities to farmers in terms of fodder availability during dry periods and provision of biomass resource for charcoal production-important financial safety nets during off seasons. This notwithstanding, the adoption of improved fallows is mainly in Southern and East Africa where over 20,000 farmers are now using Sesbania sesban, Tephrosia vogelii, and Cajanus cajan in two-year fallows followed by maize rotations. The attractiveness has been attributed to its impact on soil fertility amelioration and tangible economic benefits. Land tenure issues, lack of social capital, and improved germplasm and accessions of fallow species have been cited as constraints to scaling up. However, development of seed orchards, nursery development, and the willingness of policy makers to create a policy environment which addresses market failures and alleviates disincentives should improve adoption and future scaling up.

Acknowledgments: This work was implemented as part of the CGIAR Research Program on Climate Change, Agriculture and Food Security (CCAFS), a strategic partnership of CGIAR and Future Earth, led by the International Center for Tropical Agriculture (CIAT). We acknowledge the CGIAR Fund Council, Australia (ACIAR), European Union, International Fund for Agricultural Development (IFAD), Ireland, New Zealand, Netherlands, Switzerland, USAID, UK, and Thailand for funding to CCAFS.

Author Contributions: All authors contributed equally to the development of the manuscript and have approved the final manuscript.

Conflicts of Interest: The authors declare no conflict of interest.

\section{References}

1. Garrity, D.P. Agroforestry and the achievement of the Millennium Development Goals. In New Vistas in Agroforestry; Springer: Dordrecht, The Netherlands, 2004; pp. 5-17.

2. Partey, S.T.; Thevathasan, N.V. Agronomic Potentials of Rarely Used Agroforestry Species for Smallholder Agriculture in Sub-Saharan Africa: An Exploratory Study. Commun. Soil. Sci. Plant Anal. 2013, 44, 1733-1748. [CrossRef]

3. Pinstrup-Andersen, P. Foreword. In Integrated Nutrient Management, Soil Fertility, and Sustainable Agriculture: Current Issues and Future Challenges; Gruhn, P., Goletti, F., Yudelman, M., Eds.; International Food Policy Research Institute: Washington, DC, USA, 2000; p. 31.

4. Zougmoré, R.; Partey, S.; Ouédraogo, M.; Omitoyin, B.; Thomas, T.; Ayantunde, A.; Ericksen, P.; Said, M.; Jalloh, A. Toward climate-smart agriculture in West Africa: A review of climate change impacts, adaptation strategies and policy developments for the livestock, fishery and crop production sectors. Agric. Food Secur. 2016, 5, 26. [CrossRef]

5. Buttoud, G.; Ajayi, O.; Detlefsen, G.; Place, F.; Torquebiau, E. Advancing Agroforestry on the Policy Agenda: A Guide for Decision-Makers; Agroforestry Working Paper No. 1; Food and Agriculture Organization of the United Nations: Rome, Italy, 2013; 37p.

6. Prinz, D. Increasing the productivity of smallholder farming systems by introduction of planted fallows. Plant Res. Dev. 1986, 24, 31-56.

7. Abbas, F.; Hammad, H.M.; Fahad, S.; Cerdà, A.; Rizwan, M.; Farhad, W.; Ehsan, S.; Bakhat, H.F. Agroforestry: A sustainable environmental practice for carbon sequestration under the climate change scenarios-A review. Environ. Sci. Pollut. Res. 2017, 24, 11177-11191. [CrossRef] [PubMed]

8. Coulibaly, J.Y.; Chiputwa, B.; Nakelse, T.; Kundhlande, G. Adoption of agroforestry and the impact on household food security among farmers in Malawi. Agric. Syst. 2017, 155, 52-69. [CrossRef] 
9. Hunde, K.K. The role of Agroforestry system as strategy to adapt and mitigate climate change: A review with examples from Tropical and Temperate regions. Clim. Chang. 2015, 1, 20-25.

10. Nash, J.; Grewer, U.; Bockel, L.; Galford, G.; Pirolli, G.; White, J. Better Life Alliance in Zambia: Climate Change Mitigation as a Co-Benefit of Improved Landscape, Agroforestry, Soil, and Fertilizer Management; CCAFS Info Note; International Center for Tropical Agriculture (CIAT) and the Food and Agriculture Organization of the United Nations (FAO): Rome, Italy, 2016.

11. Kim, D.G.; Kirschbaum, M.U.; Beedy, T.L. Carbon sequestration and net emissions of $\mathrm{CH}_{4}$ and $\mathrm{N}_{2} \mathrm{O}$ under agroforestry: Synthesizing available data and suggestions for future studies. Agric. Ecosyst. Environ. 2016, 226, 65-78. [CrossRef]

12. Quandt, A.; Neufeldt, H.; McCabe, J.T. The role of agroforestry in building livelihood resilience to floods and drought in semiarid Kenya. Ecol. Soc. 2017, 22, 10. [CrossRef]

13. Bekele-Tesemma, A. Profitable Agroforestry Innovations for Eastern Africa: Experiences from 10 Agrocli-Matic Zones of Ethiopia, India, Kenya, Tanzania, and Uganda; World Agroforestry Centre, Eastern Africa Region: Nairobi, Kenya, 2007.

14. Amadalo, B.; Jama, B.; Niang, A.; Noordin, Q.; Nyasimi, M.; Place, F.; Franzel, S.; Beniest, J. Improved Fallows for Western Kenya: An Extension Guideline; World Agroforestry Centre (ICRAF): Nairobi, Kenya, 2003.

15. Mowo, J.; Bishaw, B.; Abdelkadir, A. Agroforestry in Kenya and Ethiopia. In Farmers' Strategies for Adapting to and Mitigating Climate Variability and Change through Agroforestry in Ethiopia and Kenya; Caryn, M.D., Bernart, B., Dmitriev, A., Eds.; Forestry Communications Group, Oregon State University: Corvallis, OR, USA, 2013.

16. Sanchez, P.A. Soil fertility and hunger in Africa. Science 2002, 295, 2019-2020. [CrossRef] [PubMed]

17. Sanginga, N. Role of biological nitrogen fixation in legume based cropping systems; a case study of West Africa farming systems. Plant Soil 2003, 252, 25-39. [CrossRef]

18. Ajayi, O.C.; Place, F.; Kwesiga, F.; Mafongoya, P. Impacts of improved tree fallow technology in Zambia. In International Research on Natural Resource Management: Advances in Impact Assessment; CABI: Wallingford, UK; Science Council/CGIAR: Rome, Italy, 2007; pp. 147-168.

19. Kwesiga, F.; Franzel, S.; Mafongoya, P.; Ajayi, O.C.; Phiri, D.; Katanga, R.; Chirwa, T. Successes in African Agriculture: Case Study of Improved Fallows in Eastern Zambia; Environment and Production Technology Division (EPTD) Discussion Paper; EPTD: Washington, DC, USA, 2005; p. 130.

20. Ojiem, J.O.; Franke, A.C.; Vanlauwe, B.; de Ridder, N.; Giller, K.E. Benefits of legume-maize rotations: Assessing the impact of diversity on the productivity of smallholders in Western Kenya. Field Crops Res. 2014, 168, 75-85. [CrossRef]

21. Kwesiga, F.R.; Franzel, S.; Place, F.; Phiri, D.; Simwanza, C.P. Sesbania sesban improved fallows in eastern Zambia: Their inception, development and farmer enthusiasm. Agrofor. Syst. 1999, 47, 49-66. [CrossRef]

22. Sanchez, P.A.; Jama, B.A. Soil fertility replenishment takes off in east Southern Africa. In Proceedings of the International Symposium on Balanced Nutrient Management Systems for the Moist Savanna and Humid Forest Zones of Africa, Cotonou, Benin, 9 October 2000.

23. Langyintuo, A.S.; Dogbe, W. Characterizing the constraints for the adoption of a Callopogonium mucunoides improved fallow in rice production systems in northern Ghana. Agric. Ecosyst. Environ. 2005, 110, 78-90. [CrossRef]

24. Masikati, P.; Manschadi, A.; Van Rooyen, A.; Hargreaves, J. Maize-mucuna rotation: An alternative technology to improve water productivity in smallholder farming systems. Agric. Syst. 2014, 123, 62-70. [CrossRef]

25. Orwa, C.; Mutua, A.; Kindt, R.; Jamnadass, R.; Anthony, S. Agroforestree Database: A Tree Reference and Selection Guide Version 4.0. 2009. Available online: http:/ /www.worldagroforestry.org/sites/treedbs/ treedatabases.asp (accessed on 22 June 2016).

26. Starr, F.; Starr, K.; Loope, L. Acacia Auriculiformis. Plants of Hawaii Reports. 2003. Available online: http:/ / www.hear.org/starr/hiplants/reports/html/acacia_auriculiformis.htm (accessed on 11 July 2017).

27. Nene, Y.L.; Hall, S.D.; Sheila, V.K. (Eds.) The Pigeonpea; CAB International Crops Research Institute for Semi-Arid Tropics: Patancheru, India, 1990.

28. Onim, J.F.M.; Mathuva, M.; Otieno, K.; Fitzhugh, H.A. Soil fertility changes and response of maize and beans to green manures of Leucaena, Sesbania and pigeon pea. Agric. Syst. 1990, 12, 197-215. [CrossRef] 
29. Gichuru, M.P. Residual effects of natural bush, Cajanus cajan and Tephrosia candida on the productivity of an acid soil in southern Nigeria. Plant Soil 1991, 134, 31-36. [CrossRef]

30. Ndufa, J.K. Nitrogen Dynamics and Soil Organic Matter Benefits to Maize in Pure and Mixed Species Fallows in Western Kenya. Ph.D. Thesis, Imperial College at Wye, University of London, London, UK, 2001.

31. Mutuo, P.K.; Cadisch, G.; Albrecht, A.; Palm, C.A.; Verchot, L. Potential of agroforestry for carbon sequestration and mitigation of greenhouse gas emissions from soils in the tropics. Nutr. Cycl. Agroecosyst. 2005, 71, 43-54. [CrossRef]

32. Rhoades, C.C.; Gregory, E.E.; David, C.C. Soil carbon differences among forest, agriculture and secondary vegetation in lower montaine Ecuador. Ecol. Appl. 2000, 10, 497-505. [CrossRef]

33. Silver, W.L.; Ostertag, R.; Lugo, A.E. The potential for carbon sequestration through reforestation of abandoned tropical agricultural and pasture lands. Restor. Ecol. 2000, 8, 394-407. [CrossRef]

34. Albrecht, A.; Kandji, S.T. Review Carbon sequestration in tropical agroforestry systems. Agric. Ecosyst. Environ. 2003, 99, 15-27. [CrossRef]

35. Rosenstock, T.S.; Mpanda, M.; Pelster, D.E.; Butterbach-Bahl, K.; Rufino, M.C.; Thiong'o, M.; Mutuo, P.; Abwanda, S.; Rioux, J.; Kimaro, A.A.; et al. Greenhouse gas fluxes from agricultural soils of Kenya and Tanzania. J. Geophys. Res 2016, 121, 1568-1580. [CrossRef]

36. Verchot, L.V.; Van Noordwijk, M.; Kandji, S.; Tomich, T.; Ong, C.; Albrecht, A.; Palm, C. Climate change: Linking adaptation and mitigation through agroforestry. Mitig. Adapt. Strateg. Glob. Chang. 2007, 12, 901-918. [CrossRef]

37. Baggs, E.M.; Chebii, J.; Ndufa, J.K. A short-term investigation of trace gas emissions following tillage and no-tillage of agroforestry residues in western Kenya. Soil Tillage Res. 2006, 90, 69-76. [CrossRef]

38. Millar, N.; Ndufa, J.K.; Cadisch, G.; Baggs, E.M. Nitrous oxide emissions following incorporation of improved-fallow residues in the humid tropics. Glob. Biogeochem. Cycl. 2004, 18, GB1032. [CrossRef]

39. Venkataraman, S. How Is Climate Change Affecting Crop Pests and Diseases? 2016. Available online: http: / / www.downtoearth.org.in/blog/how-is-climate-change-affecting-crop-pest-and-diseases-54199 (accessed on 11 July 2017).

40. Sileshi, G.; Schroth, G.; Rao, M.R.; Girma, H. Weeds, diseases, insect pests and tri-trophic interactions in tropical agroforestry. In Ecological Basis of Agroforestry; CRC Press: Boca Raton, FL, USA, 2008; pp. 73-94.

41. Sjögren, H.; Shepherd, K.D.; Karlsson, A. Effects of improved fallow with Sesbania sesban on maize productivity and Striga hermonthica infestation in Western Kenya. J. For. Res. 2010, 21, 379-386. [CrossRef]

42. Sileshi, G.; Mafongoya, P.L. Effect of rotational fallows on abundance of soil insects and weeds in maize crops in eastern Zambia. Appl. Soil Ecol. 2002, 23, 211-222. [CrossRef]

43. Shirima, D.S.; Otsyina, R.; Mwageni, W.P.; Bridge, J. Effect of natural and Sesbania fallows and crop rotations on the incidence of root-knot nematodes and tobacco production in Tabora, Tanzania. Int. J. Nematol. 2000, 10,49-54.

44. Desaeger, J.; Rao, M.R. Parasitic nematode populations in natural fallows and improved cover crops and their effects on subsequent crops in Kenya. Field Crops Res. 2000, 65, 41-56. [CrossRef]

45. Kandji, S.T.; Ogol, C.K.; Albrecht, A. Crop damage by nematodes in improved-fallow fields in western Kenya. Agrofor. Syst. 2003, 57, 51-57. [CrossRef]

46. Kadigi, R.M.; Tesfay, G.; Bizoza, A.; Zinabou, G. Irrigation and water use efficiency in Sub-Saharan Africa. In Policy Research Paper: Supporting Policy Research to Inform Agricultural Policy in Sub-Saharan Africa and South Asia; GDN: New Delhi, India, 2012.

47. Rao, K.P.C.; Steenhuis, T.S.; Cogle, A.L.; Srinivasan, S.T.; Yule, D.F.; Smith, G.D. Rainfall infiltration and runoff from an Alfisol in semi-arid tropical India. II. Tilled systems. Soil Tillage Res. 1998, 48, 61-69. [CrossRef]

48. Phiri, E.; Verplancke, H.; Kwesiga, F.; Mafongoya, P. Water balance and maize yield following improved sesbania fallow in eastern Zambia. Agrofor. Syst. 2003, 59, 197-205. [CrossRef]

49. Freier, K.P.; Bruggemann, R.; Scheffran, J.; Finckh, M.; Schneider, U.A. Assessing the predictability of future livelihood strategies of pastoralists in semi-arid Morocco under climate change. Technol. Forecast. Soc. 2012, 79, 371-382. [CrossRef]

50. Schilling, J.; Freier, K.P.; Hertig, E.; Scheffran, J. Climate change, vulnerability and adaptation in North Africa with focus on Morocco. Agric. Ecosyst. Environ. 2012, 156, 12-26. [CrossRef]

51. Habib, G.; Khan, N.A.; Sultan, A.; Ali, M. Nutritive value of common tree leaves for livestock in the semi-arid and arid rangelands of Northern Pakistan. Livest. Sci. 2016, 184, 64-70. [CrossRef] 
52. Khan, N.A.; Habib, G.; Ullah, G. Chemical composition, rumen degradability, protein utilization and lactation response to selected tree leaves as substitute of cottonseed cake in the diet of dairy goats. Anim. Feed Sci. Technol. 2009, 154, 160-168. [CrossRef]

53. Partey, S.T.; Sarfo, D.A.; Frith, O.; Kwaku, M.; Thevathasan, N.V. Potentials of Bamboo-Based Agroforestry for Sustainable Development in Sub-Saharan Africa: A Review. Agric. Res. 2017, 6, 22-32. [CrossRef]

54. Habib, G.; Saleem, M.; Hameed, A. Mineral composition of local tree leaves for feeding sheep and goats in Kohat district of Khyber Pakhtunkhwa. Sarhad J. Agric. 2013, 29, 97-103.

55. Elseed, A.M.A.F.; Amin, A.E.; Khadiga, A.; Ati, A.; Sekine, J.; Hishinuma, M.; Hamana, K. Nutritive Evaluation of Some Fodder Tree Species during the Dry Season in Central Sudan. Asian-Aust. J. Amin. Sci. 2002, 15, 844-850. [CrossRef]

56. Partey, S.T. Effect of pruning frequency and pruning height on the biomass production of Tithonia diversifolia (Hemsl) A. Gray. Agrofor. Syst. 2011, 83, 181. [CrossRef]

57. Abdalla, M.; Babiker, I.A.; Al-Abrahim, J.S.; Mohammed, A.E.; Elobeid, M.M.; Elkhalifa, K.F. Fodder potential and chemical composition of Acacia nilotica fruits for livestock in the dry lands of sudan. Int. J. Plant Anim. Environ. Sci. 2014, 4, 366-369.

58. Smith, O.B. Fodder trees and shrubs in range and farming systems in tropical humid Africa. In Legume Trees and Other Fodder Trees as Protein Sources for Livestock; Speedy, A., Pugliese, P., Eds.; Food and Agriculture Organization of the United Nations: Rome, Italy, 1992.

59. Devendra, C. Nutritional Potential of Fodder Trees and Shrubs as Protein Sources in Ruminant Nutrition. Available online: http:/ / www.fao.org/docrep/003/T0632E/T0632E07.htm\#ch7 (accessed on 5 June 2017).

60. Shenkute, B.; Hassen, A.; Assafa, T.; Amen, N.; Ebro, A. Identification and nutritive value of potential fodder trees and shrubs in the mid rift valley of Ethiopia. J. Anim. Plant Sci. 2012, 22, 1126-1132.

61. Van Dam, J. The Charcoal Transition: Greening the Charcoal Value Chain to Mitigate Climate Change and Improve Local Livelihood; Food and Agriculture Organization of the United Nations: Rome, Italy, 2017.

62. Partey, S.T.; Frith, O.B.; Kwaku, M.Y.; Sarfo, D.A. Comparative life cycle analysis of producing charcoal from bamboo, teak, and acacia species in Ghana. Int. J. Life Cycle Assess. 2017, 22, 758-766. [CrossRef]

63. Whiteside, M. Living Farms: Encouraging Sustainable Smallholders in Southern Africa; Earthscan: London, UK, 1998.

64. Maliki, R.; Sinsin, B.; Floquet, A.; Cornet, D.; Lançon, J. Sedentary yam-based cropping systems in West Africa: Benefits of the use of herbaceous cover-crop legumes and rotation-Lessons and challenges. Agroecol. Sustain. Food 2017, 41, 450-486. [CrossRef]

65. Kiptot, E.; Hebinck, P.; Franzel, S.; Richards, P. Adopters, testers or pseudo-adopters? Dynamics of the use of improved tree fallows by farmers in western Kenya. Agric. Syst. 2007, 94, 509-519. [CrossRef]

66. Franzel, S.; Wambugu, C. The Uptake of Fodder Shrubs among Smallholders in East Africa: Key Elements that Facilitate Widespread Adoption. In Forages: A Pathway to Prosperity for Smallholder Farmers; Hare, M.D., Wongpichet, K., Eds.; Faculty of Agriculture, Ubon Ratchathani University: Ubon, Thailand, 2007; pp. 203-222.

67. Ajayi, O.C.; Franzel, S.; Kuntashula, E.; Kwesiga, F. Adoption of improved fallow technology for soil fertility management in Zambia: Empirical studies and emerging issues. Agrofor. Syst. 2003, 59, 317-326. [CrossRef]

68. Franzel, S. Socioeconomic factors affecting the adoption potential of improved tree fallows in Africa. Agroforest. Syst, 1999, 47, 305-321. [CrossRef]

69. Place, F.; Dewees, P. Policies and incentives for the adoption of improved fallows. Agrofor. Syst, 1999, 47, 323-343. [CrossRef]

70. Sanchez, P.A. Improved fallows come of age in the tropics. Agrofor. Syst. 1999, 47, 3-12. [CrossRef]

(C) 2017 by the authors. Licensee MDPI, Basel, Switzerland. This article is an open access article distributed under the terms and conditions of the Creative Commons Attribution (CC BY) license (http:/ / creativecommons.org/licenses/by/4.0/). 